\title{
GENETIC DIVERSITY IN ACCESSIONS OF Stylosanthes spp. USING MORPHOAGRONOMIC DESCRIPTORS ${ }^{1}$
}

\author{
RONALDO SIMÃO DE OLIVEIRA ${ }^{2 *}$, MANOEL ABÍLIO DE QUEIRÓZ ${ }^{3}$, ROBERTO LISBOA ROMÃO², GRÉCIA \\ CAVALCANTI DA SILVA ${ }^{3}$, BRUNO PORTELA BRASILEIRO ${ }^{4}$
}

\begin{abstract}
The great diversity of plants in the Brazilian Semiarid environment represents a vital natural resource for the human populations of these areas. Many of these plants have been subject to extractivism and among these, the species of the genus Stylosanthes, which have occurrence in this region, show great potential, however, studies on this topic are limited, and little is known about the existing variability among these plants. Therefore, further study is necessary, to facilitate the development of cultivars. This might reduce the scarcity of fodder supply in this region, but to commence a plant breeding programme, it is essential to identify genetic variability. Therefore, this study evaluated 25 accessions of Stylosanthes spp., to identify the most suitable candidates to be parents in a plant breeding programme for the semiarid region of the state of Bahia. Two experiments were carried out in different sites in an experimental design of randomized blocks with four replicates, with a spacing of $3.0 \times 8.0 \mathrm{~m}$. A large amount of genetic diversity was observed among accessions and the genotypes BGF 08-007, BGF 08-016, BGF 08-015 and BGF 08-021 were the most divergent in the overall evaluation. For the structuring of segregating populations, it is recommended to combine the genotypes BGF 08-016, BGF 08-015, BGF 08-007 and BGF 08-006, and for the interspecific crosses, a hybrid from the accession BGF-024 with the accessions BGF 08-016 or BGF 08-015. This might generate superior individuals for mass descriptors, which are the most important for animal forage breeding.
\end{abstract}

Keywords: Semiarid. Native forage. Morphological descriptors.

\section{DIVERSIDADE GENÉTICA EM ACESSOS DE Stylosanthes spp. UTILIZANDO DESCRITORES MORFOAGRONÔMICOS}

RESUMO - A grande diversidade de plantas do Semiárido representa um recurso natural vital para as populações humanas dessa região. Muitas dessas plantas são exploradas de forma extrativista e entre elas, as espécies do gênero Stylosanthes, que são nativas tem grande potencial, porém, os trabalhos realizados têm sido modestos e pouco se conhece a respeito da variabilidade existente nessas plantas. Por isso, esforços devem ser priorizados no sentido de estudá-las, o que certamente poderá ajudar a criar formas para o desenvolvimento de cultivares e, assim, amenizar a escassez de forragem nessa região. Entretanto, para iniciar trabalhos de melhoramento, primeiro deve-se buscar variabilidade genética. Assim, este trabalho avaliou 25 acessos de Stylosanthes spp., a fim de identificar os melhores para serem genitores no programa de melhoramento genético para o Semiárido baiano. Para isso, foram conduzidos dois experimentos em diferentes locais no delineamento blocos casualizados completos com quatro repetições num espaçamento 3,0 $\times 0,8 \mathrm{~m}$. Foi constatada grande diversidade genética entre os acessos, sendo que os genótipos BGF 08-007, BGF 08-016, BGF 08-015 e BGF 08-021, mostraram-se como os mais divergentes na avaliação geral. Para a formação de populações segregantes, recomenda-se combinar os genótipos BGF 08-016, BGF 08-015, BGF 08-007 e BGF 08-006, e para cruzamentos interespecíficos recomenda-se hibridar o acesso BGF-024 com os acessos BGF 08-016 e BGF 08-015, possibilitando o surgimento de indivíduos superiores para os descritores de massa, os mais importantes para o melhoramento visando alimentação animal.

Palavras-chave: Semiárido. Forrageiras nativas. Descritores morfológicos.

\footnotetext{
*Corresponding author

${ }^{1}$ Received for publication in 04/08/2015; accepted in 01/19/2016.

Paper extracted from the doctoral thesis of the first author.

${ }^{2}$ Department of Biological Sciences, Universidade Estadual de Feira de Santana, Feira de Santana, BA, Brazil; ronaldo@agronomo.eng.br, romaoroberto@gmail.com.

${ }^{3}$ Department of Technology and Social Sciences, Universidade do Estado da Bahia, Juazeiro, BA, Brazil; manoelqueiroz@gmail.com, gcsilva@uneb.br.

${ }^{4}$ Department of Agricultural Sciences, Universidade Federal do Paraná, Curitiba, PR, Brazil; brunobiogene@hotmail.com.
}

Rev. Caatinga, Mossoró, v. 29, n. 1, p. 101 - 112, jan. - mar., 2016 


\section{INTRODUCTION}

The Brazilian semiarid region comprises approximately $11 \%$ of the country's territory and is characterized by erratic rainfall, in terms of quantity and distribution, which causes long periods of drought, with severe water deficit (ALVES et al., 2009) and results in large spatial heterogeneity in climatic conditions. The soil is also very variable. However, the most extreme situations occur in the central part of the region, where plants are subjected to major abiotic stresses. Due to these conditions, livestock has historically been a basic activity for the rural population in the semiarid region and represents the most stable economic activity, because many native forage species that provide feed for livestock are tolerant to abiotic stresses, whereas annual crops are very unpredictable, due to their increased vulnerability to environmental hazards (BANCO DO NORDESTE, 2009).

The populations of goats and sheep in the northeastern region represent $90.98 \%$ and $57.24 \%$ of the population nationwide, respectively, and the state of Bahia alone accounts for 70.11\% (IBGE, 2011). One of the biggest problems faced by animal rearing is the scarcity of forage, which is a limiting factor in the production chain, especially during drought periods (CAVALCANTI; RESENDE, 2006). The situation is more exacerbated by a sequence of dry years, as has occurred since 2012, when forage mass for animals die-offs.

The livestock production model adopted in this region, is based on the deforestation of native arboreal vegetation to establish pastures, using exotic herbaceous species, such as the genus Cenchrus spp. This practice exposes the soil and increases the risk of erosion, which coupled with overgrazing, has caused major environmental degradation and consequently, a reduction in fodder supply for livestock.

The identification of native species that are adapted to the regional soil characteristics and climatic conditions with potential as a forage crop, therefore becomes a key focus in the search for alternatives that might help to supply feed for goat and sheep herds. However, to achieve success, the existence of genetic variability for the main traits focused upon by a forage breeding programme has to be identified in these species.

The genus Stylosanthes, belonging to the Fabaceae family, shows great forage potential and members can be considered as candidate within the species for a breeding programme, because a survey for the occurrence of species of this genus in the Brazilian semiarid region revealed a great diversity in different locations, good bromatological characteristics and tolerance to degraded and dry soils (COSTA, 2006).

Despite these attributes, studies on these species in northeastern Brazil are few. When planning to start a breeding programme, it is necessary to quantify the genetic variability and to identify the most divergent individuals via biometric techniques, which can help to identify promising material that offers high mass production and a high nutritional value, and is also adapted to the soil and climate conditions and to the existing crop management. This material can then be used in a breeding programme for forage crops that thrive in degraded soils and that can be preferably used for grazing.

Thus, considering a sample of accessions of Stylosanthes from the semiarid region of Bahia as a basis, the present study investigated the genetic diversity within and among the accessions using morphoagronomic descriptors, and attempted to identify potential parents with which to create segregating populations that can be used to initiate a genetic breeding programme for these species.

\section{MATERIAL AND METHODS}

Two field experiments were carried out from July 2012 to January 2013, in two experimental units. The first site was at Horto Florestal, of the State University of Feira de Santana - UEFS in Feira de Santana, Bahia, located at $12^{\circ} 16^{\prime} 087^{\prime \prime} \mathrm{S}$ and $38^{\circ}$ $56^{\prime} 346^{\prime \prime} \mathrm{W}$, at an altitude of $243 \mathrm{~m}$. The second experiment was carried out in the experimental field of the Department of Technology and Social Sciences of the Bahia State University - UNEB in Juazeiro, Bahia, located at $09^{\circ} 24^{\prime} 50^{\prime \prime S}$ and $40^{\circ} 30^{\prime} 10^{\prime \prime} \mathrm{W}$, at an altitude of $368 \mathrm{~m}$.

The experimental design was a randomised blocks with four replications with a spacing of $3.0 \mathrm{~m}$ between rows and $0.80 \mathrm{~m}$ between plants; each experimental plot consisted of four plants, totalling 16 plants per treatment. A total of 25 accessions of Stylosanthes spp. was used (Table 1), originating from three regions in Bahia (Sisaleira region, São Francisco river region, and Feira de Santana microregion), together with the cultivar Estilosantes Campo Grande as a control. 
R. S. OLIVEIRA et al.

Table 1. Origin and description of Stylosanthes accessions stored in BGF-UEFS and used for the characterization.

\begin{tabular}{|c|c|c|c|c|}
\hline \multirow{2}{*}{$\begin{array}{l}\text { Accession } \\
\left(\mathrm{N}^{\circ} \mathrm{BGF}\right)\end{array}$} & \multicolumn{2}{|c|}{ Origin } & \multirow{2}{*}{-Year } & \multirow{2}{*}{ Species } \\
\hline & Collect site & Geographic Coordinates & & \\
\hline BGF 08-001 & Araci (S) & $11^{\circ} 36^{\prime} 20^{\prime \prime} \mathrm{S}-39^{\circ} 09^{\prime} 52.1^{\prime \prime O}$ & 2008 & S. viscosa (L) Sw. \\
\hline BGF 08-002 & Araci (S) & $11^{\circ} 27^{\prime} 24.5^{\prime \prime S}-39^{\circ} 26^{\prime} 43.6^{\prime \prime O}$ & 2008 & S. scabra Vogel \\
\hline BGF 08-003 & Ichu (S) & $11^{\circ} 42^{\prime} 24.2^{\prime \prime S}-39^{\circ} 09^{\prime} 59.4^{\prime \prime O}$ & 2008 & S. scabra Vogel \\
\hline BGF 08-004 & Serrinha (S) & $11^{\circ} 40^{\prime} 29.9^{\prime \prime S}-39^{\circ} 04^{\prime} 38.1^{\prime \prime O}$ & 2008 & S. scabra Vogel \\
\hline BGF 08-005 & Serrinha (S) & $11^{\circ} 47^{\prime} 46.8^{\prime \prime S}-38^{\circ} 53^{\prime} 24.5^{\prime \prime O}$ & 2008 & S. scabra Vogel \\
\hline BGF 08-006 & Serrinha (S) & $11^{\circ} 26^{\prime} 36.4^{\prime \prime S}-39^{\circ} 12^{\prime} 00.8^{\prime \prime O}$ & 2008 & S. scabra Vogel \\
\hline BGF 08-007 & Valente (S) & $11^{\circ} 22^{\prime} 13.0^{\prime \prime S}-39^{\circ} 17^{\prime} 28.1^{\prime \prime O}$ & 2008 & S. scabra Vogel \\
\hline BGF 08-010 & Nova Soure (S) & $10^{\circ} 29^{\prime} 36.7^{\prime \prime S}-39^{\circ} 20^{\prime} 44.0^{\prime \prime O}$ & 2008 & S. scabra Vogel \\
\hline BGF 08-011 & Valente (S) & $11^{\circ} 27^{\prime} 12.6^{\prime \prime S}-39^{\circ} 25^{\prime} 24^{\prime \prime O}$ & 2008 & S. scabra Vogel \\
\hline BGF 08-012 & São Domingos (S) & $11^{\circ} 27^{\prime} 27.1^{\prime \prime S}-39^{\circ} 32^{\prime} 46.4^{\prime \prime O}$ & 2008 & S. scabra Vogel \\
\hline BGF 08-014 & Tucano (S) & $11^{\circ} 01^{\prime} 59^{\prime \prime} \mathrm{S}-38^{\circ} 48^{\prime} 17^{\prime \prime} \mathrm{O}$ & 2008 & S. scabra Vogel \\
\hline BGF 08-015 & Queimadas (S) & 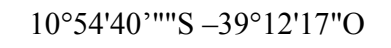 & 2008 & S. scabra Vogel \\
\hline BGF 08-016 & Queimadas (S) & $10^{\circ} 54^{\prime} 40^{\prime \prime S}-39^{\circ} 12^{\prime} 17^{\prime \prime O}$ & 2008 & S. scabra Vogel \\
\hline BGF 08-017 & Queimadas (S) & $11^{\circ} 19^{\prime} 26^{\prime \prime S}-39^{\circ} 49^{\prime} 13^{\prime \prime O}$ & 2008 & S. scabra Vogel \\
\hline BGF 08-018 & Candeal (S) & $11^{\circ} 49^{\prime} 49.8^{\prime \prime} \mathrm{S}-39^{\circ} 07^{\prime} 08.5^{\prime \prime O}$ & 2008 & S. scabra Vogel \\
\hline BGF 08-019 & Cansanção (S) & $09^{\circ} 50^{\prime} 78.7^{\prime \prime}-39^{\circ} 28^{\prime} 05.1^{\prime \prime O}$ & 2008 & S. scabra Vogel \\
\hline BGF 08-020 & Candeal (S) & $11^{\circ} 49^{\prime} 49.8^{\prime \prime S}-39^{\circ} 07^{\prime} 08.5^{\prime \prime O}$ & 2008 & S. scabra Vogel \\
\hline BGF 08-021 & Casa Nova (SF) & $09^{\circ} 16^{\prime} 50.5^{\prime \prime} \mathrm{S}-41^{\circ} 29^{\prime} 15.5^{\prime \prime O}$ & 2008 & S. humilis Kunth \\
\hline BGF 08-023 & Casa Nova (SF) & $09^{\circ} 21^{\prime} 36^{\prime \prime} \mathrm{S}-41^{\circ} 47^{\prime} 17.5^{\prime \prime O}$ & 2008 & S. humilis Kunth \\
\hline BGF 08-024 & C. A. de Lourdes (SF) & $09^{\circ} 35^{\prime} 15.1 " \mathrm{~S}-42^{\circ} 54^{\prime} 02.1{ }^{\prime \prime O}$ & 2008 & S. capitata Vogel \\
\hline BGF 08-026 & Casa Nova (SF) & $09^{\circ} 10^{\prime} 33.3^{\prime \prime S}-40^{\circ} 50^{\prime} 17.1^{\prime \prime O}$ & 2008 & S. viscosa (L.) W \\
\hline BGF 08-029 & Canudos (SF) & $09^{\circ} 54^{\prime} 29.9^{\prime \prime S}-39^{\circ} 03^{\prime} 17.2^{\prime \prime O}$ & 2008 & S. viscosa (L.) W \\
\hline BGF 08-032 & Sento Sé (SF) & $10^{\circ} 09^{\prime} 11.3^{\prime \prime S}-41^{\circ} 39^{\prime} 01.1^{\prime \prime O}$ & 2008 & S. scabra Vogel \\
\hline BGF 08-033 & Sento Sé (SF) & $10^{\circ} 10^{\prime} 22.6^{\prime \prime S}-41^{\circ} 58^{\prime} 24.0^{\prime \prime O}$ & 2008 & S. humilis Kunth \\
\hline BGF 11-034 & F. de Santana (FS) & $12^{\circ} 09^{\prime} 719^{\prime \prime} \mathrm{S}-38^{\circ} 57^{\prime} 696^{\prime \prime} \mathrm{O}$ & 2011 & S. scabra Vogel \\
\hline${ }^{*}$ Control & - & - & 2011 & S. capitata Vogel \\
\hline
\end{tabular}

*Commercial Cultivar Estilosantes Campo Grande; S: Sisaleira region; SF: São Francisco river region; FS: Feira de Santana microregion; (-): Absence of information.

The seedlings for both experiments were grown in polyethylene tubes, $6 \mathrm{~cm} \times 20 \mathrm{~cm}$ in size, with a commercial substrate Biomix $\AA$, and remained in a greenhouse with shading at $40 \%$ luminosity and intermittent mist irrigation until they reached the stage of transplantation to the field.

About three months after sowing, when the seedlings possessed true leaves, the seedlings were transplanted to previously prepared soil using a disk harrow and the plots were marked and pitted using a manual digger. The plots were fertilized by the application of $30 \mathrm{kgha}^{-1} \mathrm{P}_{2} \mathrm{O}_{5}, 30 \mathrm{kgha}^{-1} \mathrm{~K}_{2} \mathrm{O}$, and $20 \mathrm{kgha}^{-1}\left(\mathrm{NH}_{4}\right)_{2} \mathrm{SO}_{4}$ as a basal fertilizer, followed by top-dressing fertilization at about 35 to 40 days after transplantation, using $30 \mathrm{kgha}^{-1} \mathrm{~K}_{2} \mathrm{O}$ and $20 \mathrm{kgha}^{-1}$ $\left(\mathrm{NH}_{4}\right)_{2} \mathrm{SO}_{4}$ as recommended by Embrapa (2007) for the cultivar Estilosantes Campo Grande. Weeding was performed periodically and drip irrigation was applied whenever necessary, in an attempt to standardise the cultural practicesand to minimise environmental effects.

Five months after transplantation, 21 morphoagronomic descriptors were evaluated in all plants of each plot, as follows: PD - Plant Diameter $(\mathrm{mm})$ measured at the base of the plant; $\mathrm{PH}-$ Plant Height $(\mathrm{cm})$, measured from the ground level to the highest leaf on the stem; PD/PH - Plant Diameter/ Plant Height ratio; PBL - Primary branch length $(\mathrm{cm})$, which was measured from the insertion of the primary branch at the bottom of the stem to the last leaf; PAL - Length of the Central Axis of the Plants $(\mathrm{cm})$, measured from ground level to the highest leaf 
of the main stem; PBL/PAL - Primary Branch Length/Plant Central Axis Length ratio; NS Number of stems (units), by counting the number of stems from ground level to the last stem inserted on the main axis; CLL - Central Leaflet Length ( $\mathrm{mm})$, measuring the longitudinal part of the central leaflet of the third permanent leaf of the plant inserted into the first $10 \mathrm{~cm}$ of the central axis; CLW-Central Leaflet Width $(\mathrm{mm})$, measuring the latitudinal part of the central leaflet of the third permanent leaf of the plant inserted into the first $10 \mathrm{~cm}$ of the central axis; CLL/CLW - Central Leaflet Length/Central Leaflet Width ratio; LLL - Lateral Leaflet Length $(\mathrm{mm})$, measured in the longitudinal part of the right lateral leaflet of the third permanent leaf of the plant inserted in the first $10 \mathrm{~cm}$ of the central axis; LLW Lateral Leaflet Width $(\mathrm{mm})$, measured in the latitudinal part of the right lateral leaflet of the third permanent leaf of the plant inserted into the first 10 $\mathrm{cm}$ of the central axis; and LLL/LLW - Lateral Leaflet Length/Lateral Leaflet Width ratio. The mass descriptors TFM (Total Fresh Mass in g), LFM (Leaf Fresh Mass in g), SFM (Stem Fresh Mass in g), TDM (Total Dry Mass in g), SDM (Stalk Dry Mass in g), LDM (Leaf Dry Mass in g) were evaluated for a single plant per plot. Thereafter, the ratios LFM/ SFM and LDM/SDM were determined.

The accession means were estimated based on the methodology of mixed models REML/BLUP using the software SELEGEN - REML/BLUP (RESENDE, 2006). The effects of the model were tested via the LRT (Likelihood Ratio Test) and the values of the deviance analysis (ANADEV) were obtained from the difference between the complete deviations (deviances) with and without the effects of the coefficients $h_{g}^{2}$ and $r^{2}$ int using the following statistical model $\mathbf{y}=\mathbf{X r}+\mathbf{Z g}+\mathbf{W i}+\mathbf{e}$, where: $\mathbf{y}=$ data vector; $\mathbf{r}$ is the vector of effects assumed as fixed (repetition + overall mean); $\mathbf{g}$ is the vector of genotypic effects; $\mathbf{i}$ is the vector of genotype $\times$ environment interaction; and $\mathbf{e}$ is the vector of errors and residues (random) ; $\mathbf{X}, \mathbf{Z}$ and $\mathbf{W}$ are the incidence matrices for the referred purposes.

The genetic dissimilarity was estimated from the mean euclidean distance and the relative contribution of the descriptors was verified (SINGH, 1981). The cluster analyses were obtained from the dissimilarity matrix using the methods UPGMA and the Tocher optimisation method with the GENES program (CRUZ, 2013). The programming language R (R DEVELOPMENT CORE TEAM, 2012) was used to generate a dendrogram and to determine the cophenetic correlation coefficient (CCC), to validate the grouping obtained by the UPGMA method.

\section{RESULTS AND DISCUSSION}

The means and variances for the evaluated descriptors in both environments indicated genetic variation among and within the accessions, which allows the selection of genotypes that might provide genetic gains (Table 2). The largest variances were observed in the characters related to mass, confirming the wide variation and therefore the possibility of a successful selection due to the presence of relatively divergent individuals.

The ratio of the mean euclidean distance (Table 3) showed that most accessions were more distant when combined with genotypes BGF 08-007 (S, Ss), BGF 08-016 (S, Ss), BGF 08-015 (S, Ss) and BGF 08-021 (SF, Sh), revealing that these genotypes diverge furthest from the general assessment (Table 4). The accessions of $S$. scabra and S. viscosa showed similarity between the species, especially between the accessions BGF 08-029 (SF, Sv) and BGF 08-032 (SF, Ss).

The accessions BGF 08-007 (S, Ss) and BGF 08-016 (S, Ss) were the most divergent (Table 3), although both are from the Sisaleira region and have the same botanical identification, indicating intraspecific variation. This was also verified for the three accessions of $S$. humilis, which were collected in the São Francisco river region, and were less similar to BGF 08-016 (S, Ss) and were very close to each other. During the experiment and the botanical identification, striking differences were observed between the accession BGF 08-021 (SF, Sh) and the accessions BGF 08-023 (SF, Sh) and BGF 08-033 (SF, Sh), which were identified as belonging to the same species, again indicating variation within the species.

For accessions of $S$. viscosa, one of which was from the Sisaleira region and two from the São Francisco river region, BGF 08-007 (S, Ss) and BGF 08-015 (S, Ss) showed a greater divergence. In this case, the variation within species and region is notable, as although BGF 08-026 (SF, Sv) originated from a different location than BGF 08-001 (S, Sv), it was more similar to this accession than to 08-029 BGF (SF, Sv), which is from the same location. Furthermore, although BGF 08-029 (SF, Sv), belonged to the same species and originated from the same region as BGF 08-026 ( $\mathrm{SF}, \mathrm{Sv})$, it was more closely related to BGF 08-032 (SF, Ss), which comes from the same location but is a different species (Table 3).

For $S$. capitata, a high association was observed between the genotypes BGF 08-024 (SF, $\mathrm{Sc})$ and the cultivar Estilosantes Campo Grande (Sc), as they were from the same species and therefore, were close and showed similar distances. The accessions BGF 08-003 (S, Ss) and BGF 08-005 (S, Ss) were most similar, and were from the same region and share the same botanical classification. 
Table 2. Means and deviances for 25 accessions of Stylosanthes spp. and the cultivar Estilosantes Campo Grande estimated by mixed model methodology (REML/BLUP).

\begin{tabular}{lcccccc}
\hline \multirow{2}{*}{$*$ Descriptores } & \multicolumn{2}{c}{ Joint analysis } & \multicolumn{2}{c}{ Juazeiro } & \multicolumn{2}{c}{ Feira de Santana } \\
\cline { 2 - 7 } & Mean & Deviance & Mean & Deviance & Mean & Deviance \\
\hline PD & 11.15 & 3.10 & 11.81 & 2.72 & 11.53 & 3.51 \\
PH & 44.24 & 10.13 & 50.95 & 12.70 & 39.42 & 13.97 \\
PD/PH & 0.27 & 0.06 & 0.24 & 0.06 & 0.31 & 0.11 \\
PBL & 60.43 & 16.87 & 56.35 & 14.48 & 66.93 & 21.42 \\
PAL & 36.47 & 9.22 & 43.08 & 13.38 & 31.58 & 12.71 \\
PBL/PAL & 1.83 & 0.17 & 1.34 & 0.23 & 2.29 & 0.79 \\
NS & 16.06 & 3.48 & 17.55 & 4.37 & 15.31 & 4.50 \\
CLL & 13.93 & 4.46 & 11.52 & 3.54 & 16.20 & 5.83 \\
CLW & 6.59 & 1.63 & 6.08 & 1.09 & 7.04 & 2.07 \\
CLL/CLW & 2.10 & 0.23 & 1.89 & 0.37 & 2.30 & 0.43 \\
LLL & 11.01 & 1.60 & 9.12 & 2.11 & 12.70 & 4.46 \\
LLW & 4.78 & 0.63 & 4.37 & 0.84 & 5.12 & 1.74 \\
LLL/LLW & 2.31 & 0.20 & 2.11 & 0.39 & 2.50 & 0.40 \\
TFM & 116.73 & 230.96 & 559.97 & 267.23 & 1709.05 & 973.30 \\
LFM & 384.30 & 96.95 & 156.13 & 94.90 & 620.98 & 487.30 \\
SFM & 374.28 & 81.92 & 220.71 & 112.91 & 539.38 & 355.25 \\
LFM/SFM & 1.36 & 0.62 & 1.66 & 0.83 & 1.10 & 0.61 \\
TDM & 425.11 & 108.40 & 246.53 & 115.86 & 622.52 & 428.86 \\
SDM & 189.42 & 51.74 & 83.02 & 51.48 & 302.65 & 256.17 \\
LDM & 146.88 & 32.45 & 98.93 & 48.88 & 201.19 & 143.46 \\
LDM/SDM & 1.15 & 0.56 & 1.44 & 0.79 & 0.88 & 0.54 \\
\hline
\end{tabular}

*PD: Plant Diameter (mm); PH: Plant Height (cm); PD/PH: Plant Diameter/Plant Height ratio; PBL: Primary branch length (cm); PAL: Length of the Central Axis of the Plants (cm); PBL/PAL: Primary Branch Length/Plant Central Axis Length ratio; NS: Number of stems (units); CLL: Central Leaflet Length (mm); CLW: Central Leaflet Width (mm); CLL/CLW: Central Leaflet Length/Central Leaflet Width ratio; LLL: Lateral Leaflet Length (mm); LLW: Lateral Leaflet Width (mm); LLL/LLW: Lateral Leaflet Length/Lateral Leaflet Width ratio; TFM: Total Fresh Mass (g); LFM: Leaf Fresh Mass (g); SFM: Stalk Fresh Mass (g); LFM/SFM: Leaf Fresh Mass/Stalk Fresh Mass; TDM: Total Dry Mass (g); SDM: Stalk Dry Mass (g); LDM: Leaf Dry Mass (g) and LDM/SDM: Leaf Dry Mass/Stalk Dry Mass.

Table 3. Relationship of the mean Euclidean distances among 25 accessions and the cultivar (Control).

\begin{tabular}{|c|c|c|c|c|c|c|}
\hline \multirow{2}{*}{$\begin{array}{l}\text { Accession } \\
\left(\mathrm{N}^{\circ} \text { BGF }\right)\end{array}$} & \multirow{2}{*}{ Origin } & \multirow{2}{*}{ Species } & \multicolumn{4}{|c|}{ Distances between the accessions } \\
\hline & & & Bigger & Accession & Smaller & Accession \\
\hline BGF 08-001 (Sv) & $(\mathrm{S})$ & S. viscosa (L) Sw. & 1.89 & $007(\mathrm{~S})$ & 0.45 & $026(\mathrm{SF})$ \\
\hline BGF 08-002 (Ss) & $(\mathrm{S})$ & S. scabra Vogel & 1.79 & $021(\mathrm{SF})$ & 0.54 & $005(\mathrm{~S})$ \\
\hline BGF 08-003 (Ss) & (S) & S. scabra Vogel & 2.07 & $015(\mathrm{~S})$ & 0.20 & $005(\mathrm{~S})$ \\
\hline BGF 08-004 (Ss) & (S) & S. scabra Vogel & 2.42 & $016(\mathrm{~S})$ & 0.53 & $003(\mathrm{~S})$ \\
\hline BGF 08-005 (Ss) & $(\mathrm{S})$ & S. scabra Vogel & 1.94 & $015(\mathrm{~S})$ & 0.20 & $003(\mathrm{~S})$ \\
\hline BGF 08-006 (Ss) & (S) & S. scabra Vogel & 2.73 & $016(\mathrm{~S})$ & 0.47 & $007(\mathrm{~S})$ \\
\hline BGF 08-007 (Ss) & (S) & S. scabra Vogel & 3.03 & $016(\mathrm{~S})$ & 0.47 & $006(\mathrm{~S})$ \\
\hline BGF 08-010 (Ss) & $(\mathrm{S})$ & S. scabra Vogel & 2.07 & $007(\mathrm{~S})$ & 0.44 & $012(\mathrm{~S})$ \\
\hline BGF 08-011 (Ss) & $(\mathrm{S})$ & S. scabra Vogel & 1.86 & $021(\mathrm{SF})$ & 0.63 & $020(\mathrm{~S})$ \\
\hline BGF 08-012 (Ss) & (S) & S. scabra Vogel & 1.85 & $007(\mathrm{~S})$ & 0.28 & $017(\mathrm{~S})$ \\
\hline BGF 08-014 (Ss) & (S) & S. scabra Vogel & 2.15 & $007(\mathrm{~S})$ & 0.51 & $010(\mathrm{~S})$ \\
\hline BGF 08-015 (Ss) & (S) & S. scabra Vogel & 3.01 & $007(\mathrm{~S})$ & 0.33 & $016(\mathrm{~S})$ \\
\hline BGF 08-016 (Ss) & (S) & S. scabra Vogel & 3.03 & $007(\mathrm{~S})$ & 0.33 & $015(\mathrm{~S})$ \\
\hline BGF 08-017 (Ss) & (S) & S. scabra Vogel & 1.88 & Control & 0.28 & $012(\mathrm{~S})$ \\
\hline
\end{tabular}

(S): Sisaleira region; (SF): São Francisco region; (FS): microregion of Feira de Santana; (Sv): Stylosanthes viscosa (L.) W; (Ss): Stylosanthes scabra Vogel; (Sh): Stylosanthes humilis Kunth and (Sc): Stylosanthes capitata Vogel. 
Table 3. Continuation

\begin{tabular}{|c|c|c|c|c|c|c|}
\hline \multirow{2}{*}{$\begin{array}{l}\text { Accession } \\
\left(\mathrm{N}^{\circ} \mathrm{BGF}\right)\end{array}$} & \multirow{2}{*}{ Origin } & \multirow{2}{*}{ Species } & \multicolumn{4}{|c|}{ Distances between the accessions } \\
\hline & & & Bigger & Accession & Smaller & Accession \\
\hline BGF 08-018 (Ss) & $(\mathrm{S})$ & S. scabra Vogel & 1.72 & $007(\mathrm{~S})$ & 0.28 & $019(\mathrm{~S})$ \\
\hline BGF 08-019 (Ss) & (S) & S. scabra Vogel & 1.81 & $007(\mathrm{~S})$ & 0.28 & $018(\mathrm{~S})$ \\
\hline BGF 08-020 (Ss) & $(\mathrm{S})$ & S. scabra Vogel & 1.91 & $007(\mathrm{~S})$ & 0.46 & $019(\mathrm{~S})$ \\
\hline BGF 08-021 (Sh) & $(\mathrm{SF})$ & S. humilis Kunth & 2.69 & $016(\mathrm{~S})$ & 1.00 & 023 (SF) \\
\hline BGF 08-023 (Sh) & (SF) & S. humilis Kunth & 2.52 & $016(\mathrm{~S})$ & 0.43 & 033 (SF) \\
\hline BGF 08-024 (Sc) & (SF) & S. capitata Vogel & 2.54 & $007(\mathrm{~S})$ & 0.95 & Control \\
\hline BGF 08-026 (Sv) & $(\mathrm{SF})$ & S. viscosa (L.) W & 2.12 & $007(\mathrm{~S})$ & 0.45 & $001(\mathrm{~S})$ \\
\hline BGF 08-029 (Sv) & $(\mathrm{SF})$ & S. viscosa (L.) W & 2.03 & $015(\mathrm{~S})$ & 0.39 & 032 (SF) \\
\hline BGF 08-032 (Ss) & $(\mathrm{SF})$ & S. scabra Vogel & 2.07 & $015(\mathrm{~S})$ & 0.39 & 029 (SF) \\
\hline BGF 08-033 (Sh) & $(\mathrm{SF})$ & S. humilis Kunth & 2.37 & $016(\mathrm{~S})$ & 0.43 & 023 (SF) \\
\hline BGF 08-034 (Ss) & (FS) & S. scabra Vogel & 2.19 & $015(\mathrm{~S})$ & 0.33 & $003(\mathrm{~S})$ \\
\hline Control (Sc) & - & S. capitata Vogel & 2.49 & $007(\mathrm{~S})$ & 0.95 & 024 (SF) \\
\hline
\end{tabular}

(S): Sisaleira region; (SF): São Francisco region; (FS): microregion of Feira de Santana; (Sv): Stylosanthes viscosa (L.) W; (Ss): Stylosanthes scabra Vogel; (Sh): Stylosanthes humilis Kunth and (Sc): Stylosanthes capitata Vogel.

Grouping by the Tocher method (Table 4) split the accessions into seven groups. The first group consisted of 14 accessions: 13 from the species S. scabra plus the accession BGF 08-001 from the species $S$. viscosa (Table 1). Although the group consisted of different species, they originated from the same region (Sisaleira region). Group II brought together two accessions of S. scabra from the Sisaleira region, which had high results for the mass descriptors during the analysis of genotype means. Group V was also formed by two accessions from the same region and the same species, $S$. scabra, which demonstrated a high LDM/SDM ratio. Three accessions belonging to the same region (São Francisco), but to different species (two $S$. viscosa and one $S$. scabra), formed the third group. Although the accession BGF-001 ( $\mathrm{S}, \mathrm{Sv})$ is from the same species and proved to be closest to the accession
BGF 08-026 (SF, Sv), it was not included in this group (Table 3); therefore, the second group contained different species in the same group. In the fourth group, two accessions of $S$. humilis originating from the same region (São Francisco) were brought together as they had thesmallest distances; however, the accession BGF 08-021 (SF, $\mathrm{Sh}$ ) was not included in this group, even though they shared the same botanical classification and were very close to BGF 08-023 (SF, Sh) during the dissimilarity analysis. The sixth group was formed by the accession $S$. capitata (SF) together with the cultivar Estilosantes Campo Grande, which were found to be very close. Thus, although the Tocher grouping was unable to separate the accessions by species (there were two inconsistencies), the groups always contained accessions from the same region.

Table 4. Group formation by the Tocher method from the standardised mean Euclidian distances among the accessions and the cultivar Estilosantes Campo Grande (Control).

\begin{tabular}{|c|c|c|c|c|c|c|c|c|c|c|c|c|c|c|}
\hline \multicolumn{7}{|l|}{ Group } & \multicolumn{8}{|c|}{ Acessions } \\
\hline I & 003 & 005 & 034 & 004 & 017 & 012 & 019 & 018 & 002 & 010 & 020 & 014 & 001 & 011 \\
\hline II & 015 & 016 & & & & & & & & & & & & \\
\hline III & 029 & 032 & 026 & & & & & & & & & & & \\
\hline IV & 023 & 033 & & & & & & & & & & & & \\
\hline $\mathrm{V}$ & 006 & 007 & & & & & & & & & & & & \\
\hline VI & 024 & Control & & & & & & & & & & & & \\
\hline VII & 021 & & & & & & & & & & & & & \\
\hline
\end{tabular}


Using UPGMA, separation occurred through the Mojena method (1977) (Figure 1). This occurred because the adjustment between the matrix of distance and the dendrogram estimated by the cophenetic correlation coefficient was equal to 0.82 , and this indicates greater consistency of the grouping pattern (CRUZ et al., 2012).

The UPGMA grouping method separated the
25 accessions and the cultivar into five groups, which were all formed by the same species, with one exception in group III where the accessions of the different species ( $S$. viscosa) were placed together with the accessions of the species $S$. scabra and this group was also inconsistent in regard to the geographic region of origin of the accessions.

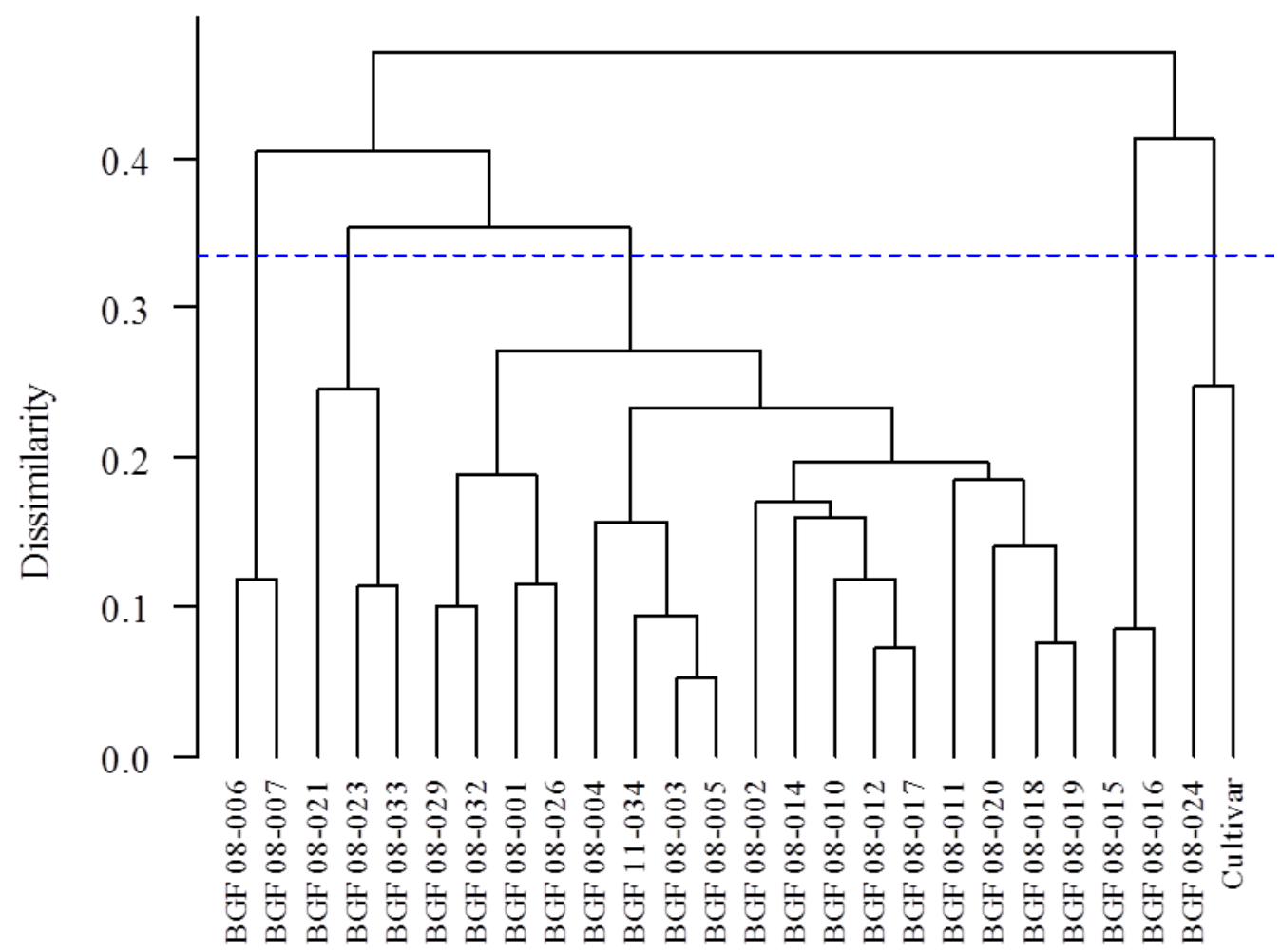

Figure 1. Dendrogram generated by the UPGMA method using the mean Euclidian distance among the accessions and the cultivar Estilosantes Campo Grande.

The first group consisted of two accessions of the species $S$. scabra originating from the Sisaleira region, thereby indicating the similarity of these genotypes, as they were the closest in terms of distance, similar to their positioning by the Tocher method.

The second group was formed by accessions BGF 08-021 (SF, Sh), BGF 08-023 (SF, Sh) and BGF 08-033 (SF, Sh), all from the same species and geographic origin; however, BGF 08-021 formed a subgroup, which showed variation within the species. The distance between the groups is notable, because the accession BGF 08-021 (SF, Sh) formed the seventh group according to the Tocher optimisation method (Table 4). For group two, both methods showed differences in the subspecies $S$. humilis and the accession BGF 08-021 (SF, Sh) was the most distant from most accessions belonging to S. scabra (Table 4). However, when the UPGMA was applied, this genotype belonged to group II, which contained accessions from the same species. This accessions hows a similar behaviour in relation to plant height to that of the two accessions of $S$. scabra in group I.

The third group consisted of most of the accessions of $S$. scabra $(82 \%)$ collected in the three different regions (Figure 1). The collected accessions of $S$. viscosa also belong to this group. These data show variation within and among regions.

The fourth and the fifth groups showed similar values for both methods. Group V consisted of the accession BGF 08-024 (SF, Sc) and the cultivar (Control, $\mathrm{Sc}$ ), and group four was created by accessions BGF 08-015 (S, Ss) and BGF 08-016 (S, Ss), which were the most outstanding accessions regarding the characters for weight and plant height. This shows the wide range of variation of this species ( $S$. scabra) and its occurrence in different regions.

It is notable that even using different criteria, neither of the two methods fully separated the groups by species and region. The grouping by UPGMA resulted in one inconsistency for separation by species only, whereas the Tocher method showed a 
high consistency regarding the origin of accessions when forming the groups (there was only one inconsistency in group I and two inconsistencies when separating the groups by species - groups I and III) (Table 4).

It was assumed that accessions of the same species and from the same region should be similar, and should differ from those from other locations. This was partially observed for the São Francisco river region. However, for the Sisaleira region, larger distances between accessions of the same species and region were observed. On the other hand, the accessions BGF 08-015 (S, Ss) and BGF 08-016 (S, Ss) from the Sisaleira region were closer to the accessions from the São Francisco river.

The results observed here for grouping by the Tocher method diverge from those of studies carried out with Stylosanthes accessions, which also used the UPGMA method (KARIA, 2008; DATE et al., 2010; MATIDA et al., 2013) and where the resulting groups correlated with the botanical varieties. The small differences regarding the formation of the two groupings can be partly explained by the criteria adopted for separation by each of the methods (ELIAS et al., 2007; CRUZ et al., 2012; LIMA et al., 2012). Generally, the first group formed by the Tocher method contains the greatest number of genotypes, because this methodology adopts the criterion that the mean distance within the group must be smaller than the distance between groups (CRUZ et al., 2012). Thus, the individuals in this group show greater genetic similarity, whereas the genotypes in the last group show greater divergence than those in the first group (ELIAS et al., 2007). When using UPGMA, groups are also established by genotypes with the greatest similarity, but the distance between a given individual and the group is expressed by the mean of all distances of pairs of individuals (CRUZ et al., 2012).

Although the methods show differences in grouping, the union of accessions belonging to different species and from different sites confirmed the remarkable presence of intra and interspecific genetic variability between genotypes, and the separation in groups occurred mainly according to the botanical identification and was little influenced by the location of the collection, especially when UPGMA was used.

However, studies with Stylosanthes in other regions of the country showed that the genetic variability between and within species of Stylosanthes is related to different regions of collection (BARROS et al., 2005; SANTANA et al., 2012), which was not observed in the present study. In other species of the genus Stylosanthes ( $S$. capitata and $S$. guianenses), the presence of pollinating insects increased the crossing rates by $31 \%$ and $26 \%$, respectively, as well as changed the fertilization rate in the progeny (SANTOS-GARCIA et al., 2011; 2012), favouring the genetic variation in this material.

The present study allowed the wide dispersion among accessions to be confirmed, mainly of the species $S$. scabra in the semiarid region of Bahia, and the presence of relatively contrasting and promising material indicates that unpredictable factors, such as the presence of pollinating insects, rainfall, luminosity and soil type, might have an effect, since the regional climate and soil characteristics differ. These factors can greatly influence the reproduction system and contribute to the emergence of a new genetic constitution and a consequent phenotypic adaptability to different environments.

Therefore, molecular studies associated with phenotypic traits are important to quantify genetic variability, as they do not depend on the environment. Similarly important is an analysis of the reproduction system of the species studied here, and the direction given to the pre-breeding studies (characterisation and multiplication), to maintain the individual integrity of the accessions, as well as to choose the breeding method to be employed for creating segregating populations of Stylosanthes for the breeding of this forage crop (RESENDE et al., 2013; RESENDE et al., 2014).

When estimating the relative importance of characters (Table 5), the most important descriptors for genetic divergence were those related to mass (TFM, TDM, SFM, LFM, SDM and LDM), which together accounted for $99.43 \%$ of the contribution, whereas the other descriptors contributed little to the differentiation of the genotypes. In the joint analysis, 15 descriptors were not important to the divergence, which makes it important to evaluate the correlations between the descriptors, to discard those that do not contribute and those that are significantly correlated with those with larger contributions, so that redundant descriptors can be excluded from future characterization assessments, thus reducing labour, as well as optimizing the use of time and resulting in cheaper experiments (CRUZ et al., 2012).

The variation in the descriptors is related to environmental factors and those that interact with the environment; thus, the behaviour of the accessions might have been influenced by unmeasured factors (COSTA, 2006; SANTOS-GARCIA et al., 2012), because the results in this study for the importance of characters differ from those of other morphological characterisations (KARIA, 2008; DATE et al., 2010; SANTANA et al., 2012), where the largest contribution to the divergence of accessions is not related to mass descriptors.

Notably, the descriptors with the largest contribution to the divergence of the accessions were those that stood out in the individual assessments and proved to be the most important ones for the breeding programme of this forage crop. These descriptors helped to select the parents for the creation of segregating populations and allowed the 
greatest probability of success through the combination of these genotypes. This can lead to transgressive individuals with a greater heterotic effect that are superior to their parents and adapted to different environments or those specific to each region.

Table 5. Relative importance of 21 descriptors for genetic divergence in Stylosanthes spp.

\begin{tabular}{|c|c|c|}
\hline Descriptors & S. j & S. j (\%) \\
\hline PD - Plant Diameter (mm) & $6,510.90$ & 0.01 \\
\hline PH - Plant Height (cm) & $69,405.59$ & 0.12 \\
\hline PD/PH - Plant Diameter/Plant Height & 2.51 & 0.00 \\
\hline PBL - Primary branch length $(\mathrm{cm})$ & $192,321.12$ & 0.33 \\
\hline PAL- Length of the Central Axis of the Plants $(\mathrm{cm})$ & $57,435.43$ & 0.10 \\
\hline $\mathrm{PBL} / \mathrm{PAL}$ & 18.51 & 0.00 \\
\hline NS - Number of stems (units) & $8,204.29$ & 0.01 \\
\hline CLL- Central Leaflet Length (mm) & $13,453.66$ & 0.02 \\
\hline CLW - Central Leaflet Width (mm) & $1,803.69$ & 0.00 \\
\hline CLL/CLW & 36.89 & 0.00 \\
\hline LLL - Lateral Leaflet Length (mm) & $1,719.27$ & 0.00 \\
\hline LLW - Lateral Leaflet Width (mm) & 268.74 & 0.00 \\
\hline LLL/LLW & 27.03 & 0.00 \\
\hline TFM - Total Fresh Mass (g) & $36,058,299.54$ & 62.42 \\
\hline SFM - Stalk Fresh Mass (g) & $6,354,501.33$ & 11.00 \\
\hline LFM - Leaf Fresh Mass (g) & $4,536,336.48$ & 7.90 \\
\hline LFM/SFM & 259.04 & 0.00 \\
\hline TDM - Total Dry Mass (g) & $7,943,148.76$ & 13.75 \\
\hline SDM - Stalk Dry Mass (g) & $1,809,787.10$ & 3.13 \\
\hline LDM - Leaf Dry Mass (g) & $711,712.83$ & 1.23 \\
\hline LDM/SDM & 213.20 & 0.00 \\
\hline
\end{tabular}

S.j: Contribution of the variable $\mathrm{x}$ to the mean Euclidean distance between the genotypes $\mathrm{i}$ and i'.

When evaluating the joint analysis for mass descriptors (Table 6), the superiority of most accessions in comparison to the cultivar Estilosantes Campo Grande became evident. Despite being the same species as the control ( $S$. capitata), the genotype BGF 08-024 showed significant and superior results. However, unlike the cultivar, this accession showed a semi prostrate habit, which indicates variation within the species and also offers the potential to be crossed to other species, since it originated in the semiarid region and is adapted to the soil and climatic conditions of the region.

The accessions BGF 08-001 and BGF 08-029, belonging to $S$. viscosa showed lower values for some mass descriptors (TFM and TDM) than the control, whereas the ratios (LFM/SFM and LDM/ SDM) were relatively higher. Despite the smaller mass indices, these accessions have less ligneous stems than the control, which makes them more advantageous in terms of nutritional forage quality and for animal consumption.

Some genotypes showed lower LDM/SDM values than the control, although the rates found in the present study are similar to those reported for the cultivar Estilosantes Campo Grande (MOURA et al., 2011) and for cultivars cv. Pioneiro $(S$. macrocephala), cv. Bandeirante ( $S$. guianensis), cv. Mineirão ( $S$. guianensis) and cv. Cook $(S$. guianensis) (TEIXEIRA et al., 2010). Although the cultivar was superior to seven accessions, its behaviour was probably influenced by environmental conditions, as the genotype was not developed for semiarid conditions, which justifies the need to develop specific genotypes for this environment. However, the potential per se of the assessed species became evident, since the values obtained in the present study were higher than those observed for the same descriptors in other species of the genus (RESENDE et al., 2006). 
R. S. OLIVEIRA et al.

Table 6. Genotypic mean of the joint analysis of the 25 accessions of Stylosanthes and the cultivar Estilosantes Campo Grande using REML/BLUP.

\begin{tabular}{ccccccccc}
\hline \multirow{2}{*}{ Accession } & \multicolumn{7}{c}{ Descriptors } \\
\cline { 2 - 9 } & TFM & SFM & LFM & LFM/SFM & TDM & SDM & LDM & LDM/SDM \\
\hline BGF 08-001 & $1,012.69$ & 618.62 & 330.48 & 1.30 & 400.70 & 165.48 & 140.17 & 1.07 \\
BGF 08-002 & $1,130.86$ & 617.71 & 408.28 & 1.74 & 425.40 & 172.19 & 160.50 & 1.41 \\
BGF 08-003 & 967.03 & 528.05 & 336.73 & 1.53 & 367.62 & 154.36 & 135.23 & 1.27 \\
BGF 08-004 & 856.85 & 482.35 & 305.38 & 2.06 & 306.93 & 132.36 & 117.69 & 1.69 \\
BGF 08-005 & $1,033.39$ & 465.36 & 348.85 & 1.41 & 388.89 & 165.21 & 137.08 & 1.15 \\
BGF 08-006 & 869.90 & 462.64 & 312.66 & 3.10 & 315.54 & 128.83 & 130.65 & 2.74 \\
BGF 08-007 & 817.25 & 431.78 & 286.69 & 3.40 & 284.63 & 122.45 & 113.39 & 3.06 \\
BGF 08-010 & $1,180.78$ & 417.21 & 339.33 & 0.69 & 471.49 & 221.00 & 134.61 & 0.55 \\
BGF 08-011 & $1,440.00$ & 409.83 & 508.17 & 1.62 & 541.79 & 231.39 & 196.69 & 1.35 \\
BGF 08-012 & $1,205.25$ & 408.68 & 365.24 & 0.97 & 471.68 & 214.88 & 149.77 & 0.83 \\
BGF 08-014 & $1,281.18$ & 397.55 & 405.63 & 0.97 & 516.24 & 229.56 & 172.30 & 0.87 \\
BGF 08-015 & $1,582.95$ & 397.39 & 582.64 & 1.08 & 704.45 & 320.52 & 240.30 & 0.88 \\
BGF 08-016 & $1,680.71$ & 353.96 & 587.96 & 1.00 & 706.21 & 325.76 & 229.87 & 0.80 \\
BGF 08-017 & $1,141.26$ & 349.69 & 354.24 & 0.91 & 443.94 & 204.24 & 138.18 & 0.75 \\
BGF 08-018 & $1,188.55$ & 333.73 & 398.29 & 1.14 & 434.49 & 192.74 & 150.37 & 0.93 \\
BGF 08-019 & $1,196.08$ & 329.95 & 374.45 & 1.00 & 458.54 & 208.59 & 148.48 & 0.79 \\
BGF 08-020 & $1,397.56$ & 324.26 & 443.91 & 0.96 & 505.56 & 231.33 & 165.62 & 0.76 \\
BGF 08-021 & 841.18 & 321.32 & 287.28 & 1.09 & 307.77 & 142.27 & 111.24 & 1.04 \\
BGF 08-023 & 921.44 & 319.97 & 325.16 & 1.29 & 336.43 & 149.68 & 125.37 & 1.16 \\
BGF 08-024 & $1,370.69$ & 312.09 & 450.81 & 0.96 & 506.91 & 241.51 & 159.02 & 0.79 \\
BGF 08-026 & $1,139.61$ & 311.70 & 366.07 & 1.30 & 386.81 & 170.93 & 137.76 & 1.07 \\
BGF 08-029 & 864.77 & 306.18 & 288.45 & 1.14 & 326.48 & 152.98 & 113.45 & 0.89 \\
BGF 08-032 & 895.80 & 304.53 & 272.97 & 1.02 & 333.26 & 152.62 & 111.81 & 0.88 \\
BGF 08-033 & 921.61 & 273.79 & 324.19 & 1.21 & 325.65 & 149.06 & 119.86 & 1.06 \\
BGF 08-034 & 949.27 & 261.35 & 334.15 & 1.43 & 351.98 & 154.89 & 130.02 & 1.20 \\
Control & $1,148.22$ & 252.08 & 393.23 & 1.04 & 433.56 & 189.96 & 149.45 & 0.87 \\
\hline
\end{tabular}

TFM: Total Fresh Mass; SFM: Stalk Fresh Mass; LFM: Leaf Fresh Mass; LFM/SFM; TDM: Total Dry Mass; SDM: Stalk Dry Mass; LDM: Leaf Dry Mass; LDM/SDM. Genotypic value $=\mathrm{u}+\mathrm{g}$ : general mean plus the genotypic effect and the interaction $\mathrm{G} \times \mathrm{A}$.

The species $S$. scabra showed the greatest positive values for the mass descriptors and demonstrated great potential for the selection of individuals with a higher mass content in semi-arid conditions, and notably, the accessions BGF 08-015 and BGF 08-016 showed the highest absolute values for these characters, together with the accessions BGF 08-006 and BGF 08-007 that showed the highest ratios for LFM/SFM and LDM/SDM. From intraspecific crosses of the accessions BGF 08-016 or BGF 08-015 with BGF 08-006 or BGF 08-007, new genetic constitutions might be generated that show a higher mass content and, moreover, a better forage quality, since they belong to the same species (S. scabra).

Directed interspecific crosses are also recommended, since the cultivar Estilosantes Campo Grande originates from crosses between $S$. capitata and S. macrocephala (EMBRAPA, 2007) and the species studied here have the basic chromosome number $\mathrm{x}=10$ and belong to the section Stylosanthes, which contains diploid species $(2 \mathrm{n}=20), S$. humilis and $S$. viscosa and allotetraploid species $(4 \mathrm{n}=40), S$. scabra and $S$. capitata (COSTA, 2006). Therefore, crosses between the accession BGF 08-024 ( $S$. capitata) and superior individuals of $S$. scabra are recommended, because they are divergent and promising for mass characters, which is the main target of the Stylosanthes breeding programme for the semiarid region of Bahia.

\section{CONCLUSION}

A large intra and interspecific genetic variability is present among the accessions collected in the semiarid region of Bahia for their assessed traits, notably for mass descriptors, which are the most important ones for a breeding programme for animal feed.

\section{ACKNOWLEDGEMENTS}

The authors acknowledge the Coordination of Improvement of Higher Education Personnel (CAPES) for the scholarship grant; The Brazilian Northeast Bank - BNB/ETENE, for financial support; the State University of Feira de Santana (UEFS) and the Department of Technology and Social Sciences (DTCS/UNEB), for support in carrying out the field experiments.

\section{REFERENCES}


ALVES, J. J. A. et al. Degradação da Caatinga: uma investigação ecogeográfica. Revista Caatinga, Mossoró, v. 22, n. 9, p. 126-135, 2009.

BANCO DO NORDESTE DO BRASIL. As ações do Banco do Nordeste do Brasil em $P$ \& $D$ na arte da pecuária de caprinos e ovinos. Série $\mathrm{BNB}$ Ciência e Tecnologia, Fortaleza, Ceará, Brasil. 2009. Disponível em: <http://www.bnb.gov.br/projwebren/ exec/livroPDF.aspx? cd livro=131>. Acess in: 12 of feb. 2014

BARROS, A. M. et al. Variabilidade genética e ecológica de Stylosanthes macrocephala determinadas por RAPD e SIG. Pesquisa Agropecuária Brasileira, Brasília, v. 40, n. 9, p. 899-909. 2005.

CAVALCANTI, N. B.; RESENDE, G. M. Consumo do mandacaru (Cereus jamacaru P. DC.) por caprinos na época da seca no Semiárido de Pernambuco. Revista Caatinga, Mossoró, v. 19, n. 4, p. 402-408, 2006.

COSTA, N. M. S. Revisão do gênero Stylosanthes Sw. 2006. 469 f. Tese (Doutorado em Engenharia Agronômica) - Universidade Técnica de Lisboa, Lisboa, 2006.

CRUZ, C. D. GENES. A software package for analysis in experimental statistics and quantitative genetics. Acta Scientiarum, Maringá, v. 35, n. 3, p. 271-276, 2013.

CRUZ, C. D. et al. Modelos biométricos aplicados ao melhoramento genético. 3. ed. Viçosa, MG, UFV, 2012. 585 p.

DATE, R. A. et al. Morphological variation and classification of field-grown Stylosanthes seabrana and S. scabra. Tropical Grasslands, Sidney, v. 44, p. 165-173, 2010.

ELIAS, H. T. etal. Variabilidade genética em germoplasma tradicional de feijão preto em Santa Catarina. Pesquisa Agropecuária Brasileira, Brasília, v. 42, n. 10, p. 1443-1449, 2007.

EMBRAPA. Empresa Brasileira de Pesquisa Agropecuária. Cultivo e uso do Estilosantes Campo Grande. 1. ed. Campo Grande: Embrapa Gado de Corte, 2007. 11 p. (Comunicado técnico, 105).

IBGE, Instituto Brasileiro de Geografia e Estatística. Produção da Agropecuária Municipal. Disponível em: <ftp://ftp.ibge.org.gov.br/Producao_pecuaria/ Producao_da_pecuaria_Municipal/2011/ pp.m2011.pdf $>$. Acess in: 27 feb. 2014.
KARIA, C. T. Caracterização genética e morfoagronômica de germoplasma de Stylosanthes guianensis (Aubl.) SW. 2008. 138f. Tese (Doutorado em Agronomia: Área de Concentração em Melhoramento Genético Vegetal) Universidade Federal de Goiás, Goiânia, 2008.

LIMA, M. S. et al. Characterization of genetic variability among common bean genotypes by morphological descriptors. Crop Breeding and Applied Biotechnology, Belo Horizonte, v. 12, n. 1, p. $76-84,2012$.

MATIDA, E. T. et al. Variabilidade genética de acessos da cultivar 'BRS Bela' de Stylosanthes guianensis usando marcadores moleculares RAPD. Ciência Rural, Santa Maria, v. 43, n. 1, p. 114-119, 2013.

MOJENA. R. Hierarchical grouping method and stopping rules: an evaluation. Computer Journal, Londres, v. 20, n. 4, p. 359-363, 1977.

MOURA, R. L. et al. Razão folha/haste e composição bromatológica da rebrota de Estilosantes Campo Grande em cinco idades de corte. Acta Scientiarum, Maringá, v. 33, n. 3, p. 249-254. 2011.

R DEVELOPMENT CORE TEAM. R: A Language and Environment for Statistical Computing. R Foundation for Statistical Computing, Vienna, Áustria. 2012

RESENDE, M. D. V. Selegen-Reml/Blup: sistema estatístico e seleção genética computadorizada via modelos lineares mistos. 1. ed. Campo Grande, Colombo: Embrapa Florestas, 2006. 305 p

RESENDE, R.M.S.; RESENDE, M.D.V.; LAURA, V. A. Genotypic evaluation of accessions and individual selection in Stylosanthes spp. by simulated BLUP method. Crop Breeding and Applied Biotechnology, Belo Horizonte, v. 6, n. 4, p. 253-260, 2006.

RESENDE, R. M. S.; CASLER M. D.; RESENDE, M. D. V. Selection Methods in Forage Breeding: A Quantitative Appraisal. Crop Science, Madison, v. 53, p. 1925-1936, 2013

RESENDE, R. M. S.; CASLER M. D.; RESENDE, M. D. V. Genomic Selection in Forage Breeding: Accuracy and Methods. Crop Science, Madison, v. 54, p. 143-156, 2014.

SANTANA, A. S. et al. Divergência genética entre acessos de Stylosanthes Sw. (Fabaceae) coletados no Semiárido Baiano. Magistra, Cruz das Almas, v. 24, n. 4, p. 304-313, 2012. 
SANTOS-GARCIA, M. O. et al. Identification of Stylosanthes guianensis varieties using molecular genetic analysis. Aobplants, Oxford, v. 1, n. 1, p.133, 2012.

SANTOS-GARCIA M. O. et al. Mating systems in tropical forages: Stylosanthes capitata Vog. and Stylosanthes guianensis (Aulbl.) Sw. Euphytica, Wageningen, v. 178, p. 185-193, 2011.

SINGH, D. The relative importance of characters affecting genetic divergence. The Indian Journal of Genetics and Plant Breeding, New Delhi, v. 41, n. 1, p. 237-245, 1981.

TEIXEIRA, V. I. et al. Aspectos agronômicos e bromatológicos de leguminosas forrageiras no Nordeste brasileiro. Archivos de Zootecnia, Córdoba, v. 59, n. 226, p. 245-254, 2010. 